\title{
DELEUZE AND THE NARRATIVE FORMS OF EDUCATIONAL OTHERNESS
}

\author{
INTRODUCTION
}

I pull my copy of Metrophage ${ }^{1}$ out of its battered pink paper folder. It is suitably badly printed, and the black and white stripes of the dysfunctional roller have left interference patterns running from the right to the left that distract the eye and make discernment of the faint courier words difficult and time consuming. I randomly separate the pages and start reading:

He stood and Nimble Virtue tossed a packet of Mad Love at his feet. It came to rest by the toe of his boot, where the water was icing up over a flaking patch of dried blood. Welding marks, like narrow scars of slag. The slaughterhouse had been grafted together from a stack of old Sea Train cargo containers. A cryogenic pump hummed at the far end of the place, like a beating heart, pushing liquid oxygen through the network of pipes that crisscrossed the walls and floor. From the ceiling, dull steel hooks held shapeless slabs of discoloured meat. Jonny looked at the slunk merchant.

Kadrey (1995, part 3, p. 1).

When we read this passage, what is the tenor of the voice that we might deploy through the use of the third person narrative? In the examination of educational narrative forms, whether through qualitative research or self-evaluation exercises, one might discern many voices that could crowd one's analytical frame. The problem for education is straightforward, and has been neatly summarised by Inna Semetsky (2004) when she said, "[A] new non-representational language of expression, exemplified in what Deleuze (1994b) called a performative or modulating aspect, is being created by means of the language structure going through the process of its own becoming-other and undergoing a series of transformations giving birth to a new, as though foreign and unfamiliar, other language,” (p. 316). This is happening as I speak or as you read these words through the immense structures and processes of the education systems of the industrialised West. Metrophage was born of these structures and now sits innocently in my office or on the internet or in the computer files of high school

\footnotetext{
${ }^{1}$ Metrophage was a cyberpunk novel that was published in 1988 by Ace Books. Richard Kadrey also put it up for free distribution on the internet, where it garnered an underground following. I chose this piece to represent a narrative form of educational otherness due to the technologically eerie and rebellious landscape that it creates.
} 
students studying for examinations to go to respectable colleges. The problem can be broken down into two parts that I shall explore throughout this chapter:

1. What are the languages of otherness that can be produced through the action of educational processing?

2. How can we use this otherness to set off new directions of educational practice and how does the philosophy of Gilles Deleuze relate to these practices?

\section{LEGITIMISATION}

The first language of otherness that is perhaps the most readily discernible in the structures of education and the most widespread - is that which subverts legitimacy. When we speak about education, we load the language that we use with knowledge statements, power concerns and rules with claims to universality. This practice is derived from the values and normative conditioning of science. JeanFrançois Lyotard (1984) in The Post-modern Condition designated the grand or overriding narrative of knowledge as being that of legitimisation. This is scientific knowledge - the legitimacy of which Lyotard (1984) indissociably linked to the legitimisation of the legislator since the time of Plato (p. 8). Thus the language called science has been strictly inter-linked with those called ethics and politics. Importantly, they both stem from the same perspective, that of the Occident, which uses various strategies to dominate other perspectives and their multiplicity of minor narratives. The development of an integrated state system has incorporated the language of scientific knowledge as one of its legitimising principles, and codes the practices of science as being its own. The state uses the procedures of science: e.g., falsification and verification, in order to maintain its authority and presence in the various language games that are played out in order to control and manipulate society. Lyotard (1984) has advised that the public have free access to the memory and data banks of the state, so that the language games may be played out with as much information as possible, though they would be, as he terms it, "non-zero-sum games," (p. 67). Michel Peters (1996) has admirably dealt with many of the political and social concerns that result from Lyotard's analysis, and has incorporated Foucault's normative historical processes into his understanding of the present educational situation. Peters (1996) indicates the ironic state of affairs that we find ourselves in, where the politicians of the liberal states continue with their grand narratives, yet social and pragmatic realities make the legitimacy of their statements almost universally untenable (pp. 79-91). For those of us caught in the middle, working inside the educational machine of Western democracies; it is as if the commands coming from the centre are being continually scrambled and dislocated by their journey into the particular localities where they are enacted. It is as if civil society (Habermas, 1999) is being continually turned upside down from its rhetorical description in government to its pragmatic maintenance through educational institutes.

What are the languages of otherness that question the legitimacy of the state and civil society and how do they relate to the philosophy of Gilles Deleuze? 
- Criminal

- Revolutionary

- Punk

- Anarchist

- Fast capitalist

- Terrorist

I could probably carry on adding elements to this list, as the subversion of legitimisation of the state, civil society and scientific language is a widespread language game. These minor narratives appear as interwoven into classrooms in one form or another through the discourses of the children and the teachers and the media where they circulate freely. They relate to Deleuzian philosophy with respect to his formulation of minor literature (Deleuze \& Guattari, 1986). In this work Deleuze \& Guattari (1986) examined the role of Yiddish with respect to Czech and German through the writing of Franz Kafka. They found that it is a language where, "minor utilizations will carry you away," (p. 25). Something similar has been happening in the education systems of the West through the relationships that have developed with respect to legitimisation. However, there is another dimension to the production of minor educational narratives of otherness that challenge the legitimacy of the state, civil society and scientific language. This is semiology, and to get closer to Deleuze's position in this field of inquiry; it is worth briefly comparing his linguistic ideas with those of Wittgenstein.

\section{LANGUAGE-GAMES}

To understand how the languages of otherness that challenge legitimisation work according to Deleuze; it is useful to note that his account of language production and control parallels that of Wittgenstein in several ways. Firstly, a basic proposal that follows from the rejection of mentalist accounts of language and thought as adequate justifications in Wittgenstein; is that the meanings of words cannot be taken away from their use, a move Deleuze (1990) made in The Logic of Sense (p. 146). The idea that there is something that is the meaning of a particular word, that can be accessed in isolation from any direct use in a specific context, is thoroughly dismantled in the Philosophical Investigations: "only someone who already knows how to do something with it," writes Wittgenstein (1998), “can significantly ask a name," (section 31) and later, '[W]hen one says, "He gave a name to his sensation" one forgets that a great deal of stage setting in the language is presupposed if the mere act of naming is to make sense,' (section 257).

This stage setting and foreground work has been translated into the legitimizing principles of education and is immanent in the sense that teachers and educators play the language-games of legitimisation through their lesson design and implementation. It could be stated that educators are trained, disciplined and domesticated through the educational machine to such a point that they tend not to be particularly aware of the abominable faculty that has been instilled in them, 
"consisting in emitting, receiving and transmitting order-words," (Deleuze \& Guattari, 1988, p. 76). This process of semiotics occurs through the inculcation of the rules of linguistic expression on the one hand; which has as much to do with gesture, body language and the significance of posture as it has to do with syntax, lexicon and the lessons of grammar. And on the other hand, semiotics works according to the networks of social practices - such as the way the day is divided up into work time and break time, or the differing and suitable modes of communication between colleagues, management and trainees that one may observe in educational establishments. The western education system has produced social praxis that is divided and streamed into appropriate behaviours for each situation in the working day. Deleuze \& Guattari (1988) call these two sides of the social machine:

1. The machinic assemblage of bodies which is training and discipline.

2. The collective assemblage of enunciation or the statements of order-words in circulation at a given point.

The difficulty of differentiating these educational strata replicates the problem in Wittgenstein of distinguishing between his corresponding terms for the machinic and collective assemblages: forms of life and language-games. We may read the two sides as mutually related, yet without directly representing one another, a relationship that Deleuze \& Guattari (1988) describe as reciprocal presupposition. This means that neither side can be adequately understood except in relation to the other; neither is primary or foundational, they both appear at once - in the double articulation of the strata. In other words, the language-games of the education system do not represent corresponding forms of life - philosophy or educational theory as exemplary practices cannot create some special language that gets more deeply into the heart of things, nor can it use "some sort of preparatory, provisional one [...it can only] use language full-blown [...] this by itself shows that I can adduce only exterior facts about language,” (Wittgenstein, 1998, section 120). Why is this the case? It is because language has no interior. As Deleuze \& Guattari (1988) have said, "If language always seems to presuppose itself, if we cannot assign it a non-linguistic point of departure, it is because language does not operate between something seen (or felt) and something said, but always goes from saying to saying” (p. 76). Thus the languages of otherness that spring from the immense source of western legitimisation and that are enacted through the organisation of education (language-games or order-words that reciprocally presuppose the forms of life or assemblages); pass on their codes from word to word. In addition, these methods of semiotic dissemination are strengthened through the electronic methods of communication that are now available such as the internet and SMS messaging.

The analysis of Deleuze \& Guattari (1988) gives us a battery of material relations, and an open-ended series of concepts that can be applied or ignored as the investigation dictates; as we explore ever further into the narrative forms of educational otherness. The pivotal notion for them is double articulation, the separation of material flows of bodies, events and signs into two reciprocallypresupposing levels. It could be said that Wittgenstein's terms language-game and form of life designate the double articulations of the social machine, which 
Deleuze \& Guattari (1988) call respectively the collective and machinic assemblages. On either side, two opposing tendencies can be observed, one towards stability and regularity, and the other towards creation and change. In Wittgenstein's terms, the former would be speech-actions in accordance with grammar - or on the larger scale, unproblematic and smooth social functioning in the educational machine - while the latter is seen in his various examples of the inability to apply grammar rules correctly, and of attempts to misuse language in this context that would seem to encapsulate narrative forms of otherness. Wittgenstein presented the possibilities of language malfunction as peculiarly illogical practices; that have greater significance than just getting words wrong. However, by emphasising this ever-present possibility; he has taken the focus away from separate, exclusively linguistic problems. Furthermore, Wittgenstein has fused errors in with the complex and interwoven threads of language, thought and social behaviour that are inseparable, and indeed produced by the education machine; as it works to make disciplined and domesticated subjects that might be controlled through language in terms of getting the orders right. Perhaps this is just the common state of humanity, as Wittgenstein (1998) suggests when he writes:

Suppose you came as an explorer into an unknown country with a language quite strange to you. In what circumstances would you say that the people there gave orders, understood them, obeyed them, and rebelled against them and so on? The common behaviour of mankind is the system of reference by means of which we interpret an unknown language (section 206).

Whilst taking the analysis further by squarely looking at the problem of otherness in terms of control - or the order-words and machinic assemblages that educators employ; Deleuze and Guattari (1988) do agree on the social nature of language and the resultant language-games. Wittgenstein leaves us hanging in terms of the relationship between language and the modes of existence that might help us to escape from these interminable games. It is for him an uncanny fact of language production that the use-value we ascribe to it is invariably tied up with the control and regulation of behaviour. I want to say that there is a way out of this conundrum, and it is through the philosophy of Gilles Deleuze, particularly when he has written in conjunction with Félix Guattari $(1984,1988)$. This escape route is located deep inside the heart of creating language. There the otherness that spreads immanently through the education system as educators enforce the principles of legitimisation through language-games is not apparent. It is a place wholly encapsulated by desire.

\section{THE LANGUAGE OF DESIRE}

This place of desire has been a site for serious intellectual and educational investigation. It has involved research into the hybrid, asignifying, non-linear narrative forms of otherness that are currently developing around the globe - and 
owes much to the interventions of feminist, cybernetic and experimental social scientists and their "common notions" (Parisi, 2004, p. 200). Their efforts have not developed immutable equations or formulas to structure research into the nature of desire; but they have extracted themes of a qualitative and local nature. These themes may have been hidden due to previous explorations that adhered to the disciplinarian codifications of power and not conforming to the perturbations of desire. This quote from Sandra Harding explains what to look for in our application of Deleuzian philosophy to education:

Once we stop thinking of modern Western epistemologies as a set of philosophical givens, we can begin to examine them instead as historical justificatory strategies; as culturally specific modes of constructing and exploiting cultural meanings in support of new kinds of knowledge claims (Harding, 1986, p. 141).

Deleuze sets up 'the other' as the focus of inquiry, Harding specifies the discourses to be analysed. One aspect this research into the narratives of otherness and desire has been characterised as cyber-feminism. It is the opportunity for the expression and elaboration of difference in opposition to any tyranny of the status quo, or the world-view of institutionalised structures of patriarchal control (Shields, 1996, p. 9). Studies such as those of Anne Balsamo (1996) or Veronica Hollinger and Joan Gordon (2002) have placed the cyborg figure of Donna Haraway (1991) at the leading edge of an interruption in male dominated knowledge and narrative. It could be said that to render the technological figure as feminine (but not a subject), is a tactical manoeuvre designed to impinge upon our perceptions and understanding of the processes that are being analysed in education and through creating otherness. In the case of investigating a language of desire, the questions applicable to contemporary narrative forms shift from those that feed into a categorical mechanism concerned with formulating a 3-dimensional structure that effectively co-ordinates the integration of language in society; to a flat perspective, where the paradigms of communication and data-inter-relatedness change from peripheral objects of the curriculum to central figures filled with desire (Parisi, 2004, p. 195). This feminist perspective strategically stays on the edge of educational discourse, where the difference opened up by the desire to be involved with narrative experimentation, may not be forced back into previously coded and recognised forms, but has a nomadic position (Deleuze \& Guattari, 1988, p. 431).

This insight into creating a language of desire concurs with Sue Golding's (1997) collection of writings that have presented eight technologies of otherness. In this work she defined otherness as, "simply and only a cosmetic wound; a very thin, virtual, and in this sense 'impossible' limit," (p. 7). It could be stated that Golding's collection of essays sets out to rethink the notion of otherness. It is generally assumed that the other, or otherness, is something that does not fit in technically speaking. But then this supposition may lead to a slide, and that change in position turns into a human object, so otherness becomes, for example, woman, the black or Jew, or in our case the misbehaving child. This other is therefore the 
group that doesn't fit in with what was being framed in the first place; in education the normative concerns are the narrative forms of conformity, regulation and control that exclude otherness. In the eight technologies of otherness, otherness is strategically placed as a surface, and that surface is both the expression of the subject and that which is not part of the object. For example, to say that 'the thing' has pain in it is only accurate in as much as the object you are dealing with has pain in it, and the part that is otherness, the other entity is only comprehensible in as much as it is related to, in this case, a body. Otherness thus has this peculiar property to it, which is that it both frames something and simultaneously has no life on its own. Up until very recently most social scientists were dealing with otherness in the same way that physical scientists would look at atoms; and therefore they did not take into account the relational quality of otherness. It could be said that we require something different for contemporary society where information carries the load of relational forms and is characterised by fluidity and changes in nature. The technologies of otherness of which pain is one, though it is named by Sue Golding in her book as cruelty (Figure 1); fit in to the being or the entity, and could also be perceived as at the same time passing through 'the thing'. The technologies of otherness are part of the excess of the object, and yet they make up the thing itself. In so doing these technologies may produce a language of desire, or a non-representational language to use for the narrative forms of educational otherness. 


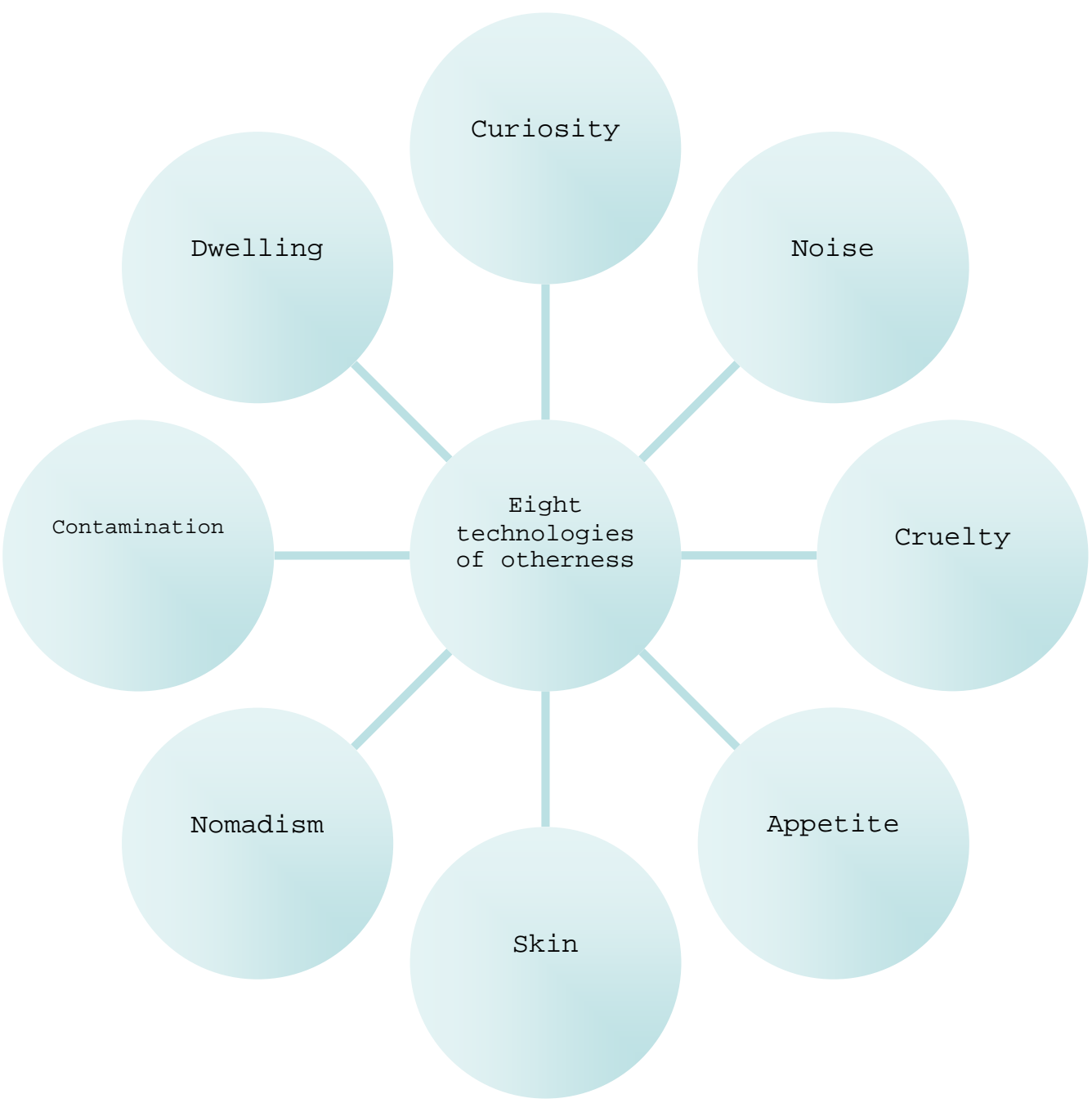

Figure 1. Sue Golding's (1997) eight technologies of otherness

This schema could be used as a way of understanding desire in language in terms of capturing non-representational otherness. It is worthwhile to point out that in 1977 Deleuze wrote a personal set of notes for Michel Foucault. In them he said, "...desire does not comprise any lack; neither it is a natural given; it is an assemblage of heterogeneous elements which function; it is process, in contrast with structure or genesis; it is affect, as opposed to feeling; it is haeccity 


\section{DELEUZE AND THE NARRATIVE FORMS OF EDUCATIONAL OTHERNESS}

(individuality of a day, a season, a life), as opposed to subjectivity; it is event, as opposed to thing or person. And above all it implies the constitution of a field of immanence or a 'body without organs', which is only defined by zones of intensity, thresholds, gradients, flux," (p. 11). One might see how a language of desire would be constituted through these statements about desire. In particular, the body without organs is a powerful figure to reconceptualise education working around sexualities, desire and the construction of the self. We might ask ourselves: do our educational practices enable this language? It is a paradox of otherness that it is defined by movement, yet there is also something 'in it' such as has been captured by the categories of the eight technologies of Sue Golding or the body without organs. To explore this element of educational narrative otherness further, we must examine Deleuze \& Guattari's notion of nomadism and how it relates to language and education. Nomadism cannot be constituted through otherness or as a relative force against the sedentary power that is immanent in the state and civil society control of education in the West. Nomadism should be understood 'in-itself' to the extent that it may be used as a critical tool to enable a language of desire that may express otherness.

\section{NOMADISM}

To understand what Deleuze \& Guattari (1988) mean by nomadism; we first need to state that the narrative styles, sources of information and types of knowledge claims change when we question the power structures that have been upheld and are indeed upholding the educational and administration systems of the West. For example, the writer and experimental artist Manuel de Landa, has posited the notion of pandemonium (Selfridge, 1958) as being defined by when messages are not sent to specific locations, but are broadcast to concurrent independent objects. Therefore, control of the system is relinquished from a uni-directional (A-B) approach where A controls B and now spreads smoothly in the space of simultaneous message-recipient relationships. An example of pandemonium was the operation of numerous Jacquard looms - at the same time - during the Industrial Revolution (Landa, 1991, p. 164). As such, pandemonium is not exhausted by definition as a humanist-historical concept, or as a scientific-realist perception; it may be more appropriately defined as an [inhuman-chaotic-immanent procedure] it is a counter strategy to the rendition of the loss of power by humans due to machines or the direct transfer of system control to simultaneous digital environments in the contemporary workplace (Murphie, 2005, p. 19).

Pandemonium has been happening through education in highly industrialised countries via the introduction of technology into the learning process (New London Group, 1996). Technologies such as SMS or the internet are fast and beguiling forms of communication that enable learners to talk to each other immediately. Nomadism in this context is the fluidity and movement that is produced by this technology. It also simultaneously creates the conditions of otherness in that subjects and words of command and power may be emptied of meaning in an electronic and mediated state. The analysis of Deleuze \& Guattari (1988, pp. 351- 
424) have named this tendency as the war machine; and they track it through history where technology has promoted new social forms such as armies and more recently the simulation of war games in virtual reality. The nomadism of contemporary society concerns the knowledge of control mechanisms, tracking immanent, nano and macro-tendencies, and should not attempt to undo societal and educational ruptures in favour of the rhetoric of government or the 'civilised' West. It could also be stated that pandemonium is a useful rubric for educational narrative research on otherness and a coherent formulation of Deleuze \& Guattari's nomadism.

In contrast to Deleuze \& Guattari's (1988) narrative perspective of the nomad that might be enacted through pandemonium; technological society was theorised from a static historical-humanist perspective by Jacques Ellul (1964) in The Technological Society, through which he examined the political consequences of a society of technicians. As a well-known precursor of Deleuze \& Guattari, this approach opens up the way in which they have radicalised educational narrative forms by introducing nomadism into authorial legitimisation and the resultant language of desire. Contrariwise, Ellul tracked the development and placement of technique from a fixed position - and found it to be constituted by regimes of technical knowledge with useful applications that have been organised by social groups concerned with power. Technique was designated as being mobile, following the divisions of Zweckwissenschaft - the practical sciences - in order to lay waste to various moral and political regimes such as organised religion, usually to the benefit of a state system (Ellul, 1964, p. 317). In a similar way to Jünger (1949a), the question of whether technical disciplines are able to centralise in autonomous economic and political systems, does not preclude lateral communication between technical epicentres, as techno-Zeitgnosse - or technologised contemporaneity (p. 121). This contemporaneity fuses technical expertise with the ability to communicate the particular knowledge as an integral part of the activity. In this way, the medium for mediation is singularised (Jünger, 1949b); and it could be said that this is happening at a breakneck pace in the current globally inter-linked information world, where the narrative forms of education are evolving into new and mutated formats due to factors such as the internet and SMS messaging. The nomadic war machine (Deleuze \& Guattari, 1988, p. 420) of A Thousand Plateaus is a schema whereby this mutation may be tracked, and integrated with a radicalised cyber-feminist analysis (Parisi, 2004, p. 200). As such it is an important formulation that helps us to understand how the sedentary power of the institutions of the West is being undermined by the augmented regimes of movement that they are ironically producing. Yet to comprehend the breadth of this conjunction fully; we must understand how Deleuze constructed the nomadic war machine as a singular idea for technological movement through his engagement with philosophy. 
DELEUZE AND THE NARRATIVE FORMS OF EDUCATIONAL OTHERNESS

\section{SINGULAR OTHERNESS}

The intellectual construction of the notion of the nomadic war machine starts with Deleuze's (1994a) reading of western philosophy in Difference and Repetition. According to Deleuze, the diaphora of Aristotle is a false transport. Deleuze argues that diaphora never shows difference changing in nature; we never discover a differenciator of difference, which would relate in respective immediacy, the most universal and the most singular. This is vital when describing the mechanisms of technological transformation. The differenciator for Deleuze differenciates difference in-itself, and is a component in his ontological exploration of generalised anti-Hegelianism and the Heideggarian philosophy of ontological Difference. Deleuze reverses the ontological methodology of positing substance or being as the grounds for asking the questions, "How does matter change?" (Aristotle), or "How can being gain determinacy?" (Hegel), or "How can being sustain its difference?" (Heidegger); instead, Deleuze asks the question, "How can difference sustain its being?” Michael Hardt (1993) has located the source of Deleuzian ontology in Bergson, where internal difference has been elevated to the level of the absolute (p. 7); in contrast to Mechanism or Platonism, where difference is thought of contingently (per accides). In attempting to think internal difference, Deleuze wishes to ground being in difference, whereupon the internal difference is not conceived as simple determination; but achieves 'substantial differences' (per se).

Deleuze pursues the philosophical point about difference to set up a new perspective on singularities. This relates to the construction of the war machine and otherness in education in that the technological regimes of intensity where nomadism is enacted is not a particular occasion of innovation or social instance of augmented peculiarity. It is characterised more definitely through the use of singularities. Singularity for Deleuze is beyond particular propositions no less that universality is beyond general propositions. Here the echoes of Deleuze's project resonate with those of Whitehead. Whitehead (1978) proposed propositions as hybrids of pure potentialities and actualities (p. 185). Singular propositions for Whitehead contain the potentiality of an actual world including a definite set of actual entities in complex reactions. Deleuze and Whitehead diverge to an extent at this point in that Whitehead wished to extend actual entities to set up relations with eternal objects or "predicates of the proposition," (Whitehead, 1978, p. 186). The singular proposition for Whitehead includes in its potentiality the complex predicate finding realisations in the nexus of reactions between logical subjects (the definite set of actual entities). Deleuze (1994a) pursued the argument by turning to problematic Ideas in Difference \& Repetition rather than remaining on the level of singular propositions. Problematic Ideas are not simple entities, but are multiplicities or complexes of relations and corresponding singularities. For Whitehead, the question of the problem is figured in relation to actual entities, each with their own formal existence, entering into objective relations with the actual entity in question. The answer for Whitehead (1978) is to posit the "creative action of the universe" (p. 56), always becoming one in a particular unity, and adding to the multiplicity of the universe as many. This for Whitehead is the concrescence 
into unity, which every entity must enter into as a result of its creative action and the establishment of new relation, which Whitehead (1978) termed as innovative becoming (p. 79). Deleuze (1994a) characterised the problem of thought by the distribution of the singular and the regular, distinctive and ordinary points taking place within the description of a multiplicity in relation to the ideal events which constitute the conditions of the problem (p. 189). The problem for western education is the production of otherness in its very folds.

It could be said that Deleuze and Whitehead both worked on the problem of otherness in complementary manners. The work of Deleuze (1994a) and Whitehead (1978) is comprehensible as parallel yet distinctive projects that add philosophical detail to the action of singularities as nomadic others in technological environments; however, I would not wish to posit an identity or assemblage, such as Deleuze-Whitehead, in the manner that Alain Badiou (1994) does in his essay concerning The Fold. The creative difference of Platonic Forms in Whitehead, opposes the actual difference of singularities in Deleuze. Both thinkers are joined more definitely in their appropriation of Bergsonian notions of durée and intuition, and a dynamic relationship to science. In Whitehead's (1978) terms, temporal endurance (durée) depends on subjective aim; his expression for Bergson's intuition is conceptual prehension. This temporal endurance selected for any one actuality, determines how the extensive continuum is atomised by atomic actualities of a locus in the "unison of becoming" (p. 128). Whitehead's philosophy of the organism which presents a coherent cosmology for science in terms of process, then establishes the foundations for mathematical expression of physical science. These complex categoreal conditions (Whitehead, 1978, pp. 219-283) consist generally in satisfying some condition of a maximum, to be obtained by the transmission of inherited types of order. Otherness in this sense is dependent on time concerns in the individual that might extend and create this sensation as working processes. Whitehead would therefore diagnose the narrative forms of otherness in the education system as deriving their nature from relative and interactive worlds of mediation that are being created through the technological and augmented regimes of change that have swept through highly industrialised countries.

Deleuze (1988), on the other hand, has highlighted the Bergsonian schema for time which unites Creative Evolution and Matter and Memory, and is a contrasting way of examining the virtual transformations that are happening due to the post-modern nomadism in contemporary society. Deleuze worked by beginning with an account of a gigantic memory, a multiplicity formed by the virtual coexistence of all sections of a cone (p. 60), each section of the cone is a repetition of all the others and is distinguished from them only by the order of relations and the distribution of singular points. The one-whole point of unity in Whitehead and the Platonists is for Deleuze (1988), a virtual point, where duration is difference in kind, in itself and for itself. Differences in kind and degrees of difference coexist in a Single Nature through the virtual point, where Bergson spoke of different intensities and degrees in a virtual coexistence, in a single Time or simple Totality (p. 94). Actualisation of 


\section{DELEUZE AND THE NARRATIVE FORMS OF EDUCATIONAL OTHERNESS}

the unity take the form of divergent lines, each of which corresponds to a virtual section and represents the incarnation of the order of relations and distribution of singularities peculiar to the given section in differenciated species and parts (Deleuze, 1994a, p. 212). Singular otherness is therefore the workings of this virtual point according to Deleuze. It is not the idealism of the Platonic forms of Whitehead. On the contrary, the production of the narratives of otherness is a communal affair, based on the material condition for the war machine, such as the companies that produce software for virtual war games. It is in a state of heightened intensity due to global conflict and differing ideologies coming into contact through material concerns such as the need for oil. In terms of education, the Deleuzian perspective is to explore the workings of the virtual point and to disseminate strategies that make the singular otherness that is harnessed through virtuality real for the students. This approach corresponds to the recent ideas of James Gee (2004), in which he suggests that virtual reality games act as conduits for complex learning behaviours that would stimulate interest in mainstream literacy practices.

The direction of the Deleuzian argument leads against multiplicities conceived of as numerical, quantitative multiplicities, of the kind G.B.R. Riemann and Einstein (Einstein, 1920) have proposed. For example, when speaking about Freud's psychoanalysis of the Wolf-Man; "These variable distances are not extensive quantities divisible by each other; rather, each is divisible, or 'relatively divisible', in other words, they are not divisible below or above a certain threshold, they cannot increase or diminish without their elements changing in nature," (Deleuze \& Guattari, 1988, p. 31). The Bergsonian suggestion, in contrast to quantitative multiplicities, is of qualitative multiplicities which found differences in nature, rather than merely being "of degree" (Hardt, 1993, p. 13) and difference is therefore founded 'in kind'. However, qualitative and quantitative multiplicities do not act dualistically, but given Bergson's durée, act from unity to multiplicity, virtuality to actuality. Deleuze does maintain ground for the ideal or transcendental in the virtual, but his process of actualisation is not a degradation or copy in the real; but it is uses the creative, immanent, explosive force of life itself.

Thus Deleuze came upon his formula for creativity through intense philosophical work. These explosive acts that he has used in order to constitute qualitative multiplicities may join together in libidinal action or in the form of desiringmachines. In the context of educational otherness and narrative forms, the rebellious and anti-disciplinarian discourses in our education systems are animated and driven by such forces. This is why Deleuze, perhaps resting heavily on Nietzsche and Spinoza, gives us the freedom to track otherness down to its root causes. The nomadic otherness (or war machine) that is set free by the internet and SMS messaging; is vitalised by the singularity of its expression and the sexual power that it evolves in concrescence. In addition, a "new transversal subjectivity emerges, which takes others as constitutive moments in the construction of a common plane of becoming," (Braidotti, 2005, p. 10). 
DAVID R. COLE

\section{RELATIVE AND CONSUMER OTHERNESS}

If we dig deeper into the nomadic otherness that is produced by technologies such as the internet and SMS messaging, we find the commercial mores that characterise late or fast capitalism. It is all too easy, as Deleuze \& Guattari (1988) put it, to get carried away with a kind of "science fiction" of micro-connectivity (p. 422). The retention of an exterior approach to the artefacts and processes involved with learning in contemporary global society is to construct a perspective of cybermaterialism. This complex position retains the exteriority of desire and its many connections (Murphie, 2005, p. 18), so that they may not hidden by the mind seeking knowledge in education or idealism - even if it is in a micro or local and qualitative sense. It is also in line with contemporary sociological investigations:

...the consumer takes on the role of the agent of aestheticization, or of branding. For example, the tourist consumes services and experiences by turning them into signs; by doing the semiotic work of transformation...it turns referents into signifiers. This is one sort of the demand-side of semiotic work that characterises what Featherstone calls the aestheticization of contemporary everyday life....this aestheticization leads to an endless profusion of space odysseys- subjects \& objects travelling at increasingly greater distances and speeds. Objects are emptied out of meaning and material content (Lash \& Urry, 1994, p. 15).

Deleuze \& Guattari (1984) explored these processes most effectively in Anti Oedipus. In this work, the micro processes of integrated otherness are spread on a global economic and political plane. They are summarised through the conjunction, desiring-machines. This figure is still relevant today as the machinic qualities of fast information based capitalism mesh ever deeper into the languages of desire that we might formulate. As Claire Colebrook (2002) has expressed it, "Any practice, technology, knowledge or belief can be adopted if it allows the flow of capital,” (p. 127). This is a serious point for education, as it puts any intellectual work under pressure, as Bronwyn Davies (2005) has vigorously explored in terms of neoliberalism. She signals at the end of her piece an escape route through desire, that constitutes as she puts it, "narratives and storylines, the metaphors, the very language and patterns of existence through which we are subjected and made into members of the social world,” (p. 13). Deleuze does take us further into the language of desire as he opposes subjectification by positing desire in terms of the plane of becoming or immanent nomadism. In terms of education, there is no hiding place from fast capitalism in the human subject and the tendency to use emotional language; as it has been thoroughly and effectively hollowed out through marketing and the expression of desire for products. Immanent nomadism escapes such relative emptiness through the possibility of singular otherness and the formulation of a constitutive language of desire that is formed as Sue Golding (1997) has expressed it through the construction of a surface or immanent material plane of change. 


\section{DELEUZE AND THE NARRATIVE FORMS OF EDUCATIONAL OTHERNESS}

This perhaps brings us close to the kind of desire that reflects the narrative forms that we find in contemporary educational otherness. The speedy circulation of objects emptied of meaning creates a type of aesthetic experience which is thoroughly mediated. It is tempting at this point to make the conjunction constituted by Deleuze-Baudrillard, in that we have reached a similar level of 'object politics' (McLaren \& Leonardo, 1998, pp. 215-243), where the work of the two theorists may be joined. Yet Baudrillard does not leave an escape route from the submergence of multifarious sign-symbol relationships, and the ways in which consumer otherness may belittle and dominate education. Deleuze, on the other hand, does give educational theory credence, and the mapping out of the narrative forms of educational otherness that have been presented in this chapter provides 'lines of flight' (Leach \& Boler, 1998, pp. 159-163) for education. Deleuze \& Guattari (1988) originally used the phrase, 'lines of flight' in A Thousand Plateaus; where it signifies that every social phenomena includes escapes and inversions, and it is in these lines of flight that the escape from organisation and centralisation happens; it is a process of leaking between categories. The learning process in this context is condensed in time and extended through space - it communicates a sense of mutated and unreal reality (Ansell Pearson, 1999, p. 113). The curriculum sits on this sense of unreal and accelerated reality as a hyper site of mediation, rather than a stable overlay of categories of learnt knowledge, skills or process that might depress this sense of unreality.

\section{CURRICULUM OTHERNESS}

It is a fact of any educational innovation that nothing will change in schools unless teachers are included and part of the new programme (Seaton, 2002). The most pressing issue for them is going to be in terms of curriculum reform that would incorporate the narrative forms of educational otherness into the production and functioning of their lessons. Important questions that should be asked to aid this incorporation include:

- How can teachers use the effects of legitimisation and the ways in which minor narratives are created that challenge meta-narrative status?

- What are the language-games that deal with otherness?

- How can teachers use the language of desire?

- How can nomadism help to generate engagement and interest in lessons?

- How does the notion of singular otherness infuse teaching practises?

- What are the lessons of relative and consumer otherness that would augment knowledge provision?

To help answer and structure these questions, and to put forward a Deleuzian curriculum of otherness, I have formulated these ideas into a knowledge curriculum diagram: 


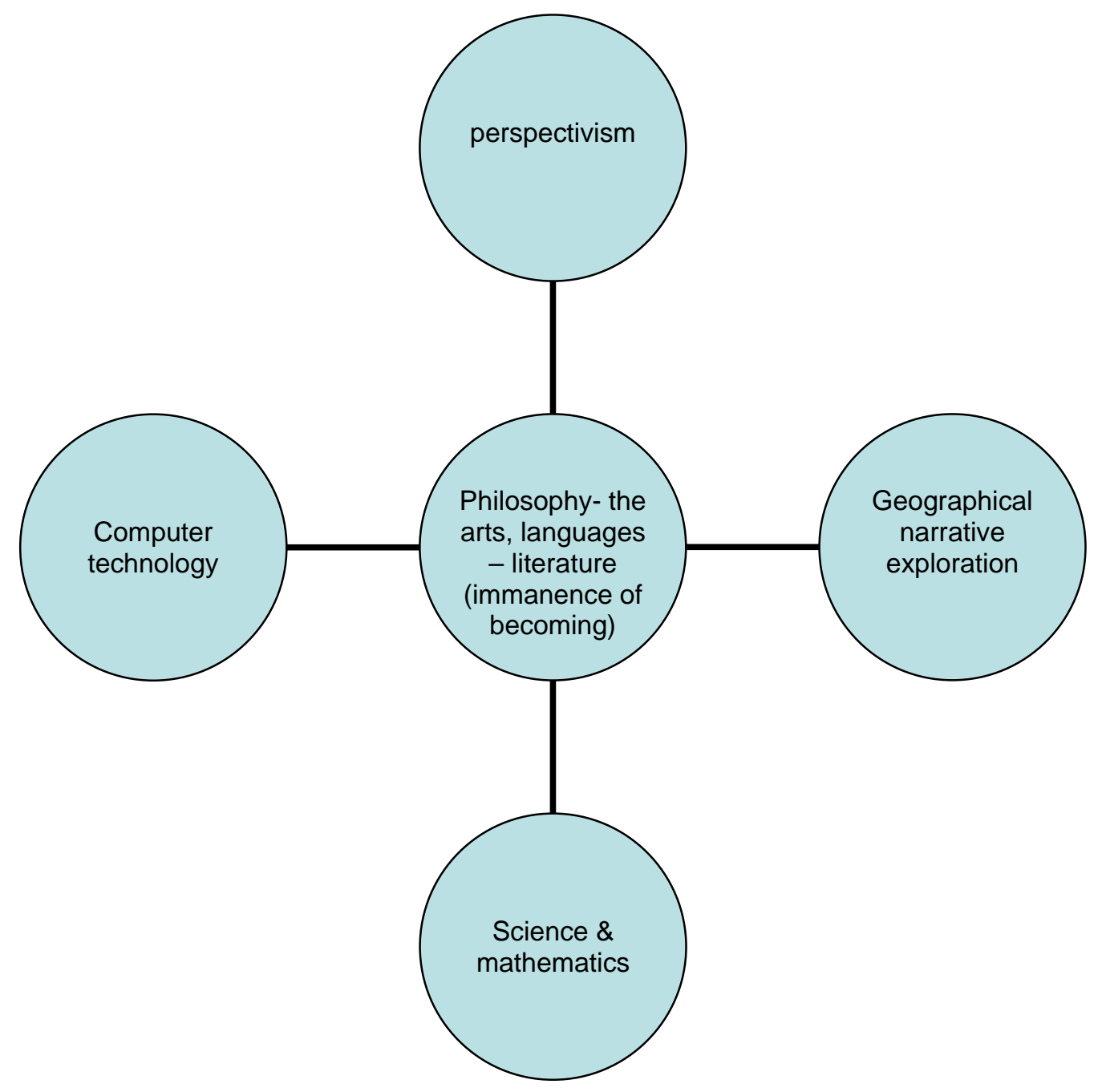

Figure 2. Deleuzian curriculum of otherness.

- The narrative form of history would embrace 'perspectivism' through the understanding and insider knowledges of multiple cultures and time periods rather than mono-culturalism (imperialism). 
- Geographical narrative forms should extend from the study of 'natural processes' into urban space, discursive space and surveillance (Davis, 1990).

- The learning of science and mathematical narrative formats should act as a kind of intellectual buffer zone before embarking on creative application of these formats.

- Computer technology sits at the heart of the acceleration in the circulation of signs and emptied signifiers and should be immanently attached to cultural significance rather than merely learnt code.

- The narrative forms of philosophy, the arts, foreign languages and literature should be central to the curriculum and the way in which mediation is dealt with through educational research and organisation.

This simple curriculum framework for construction should act to enable teachers and students to explore otherness and the ways in which it is present in our narrative formats in education. It is by no means prescriptive or definitional with respect to the type of content material the teachers might look to insert into each part off the curriculum, as this will wholly depend on local needs and wishes. What this curriculum does is encourage substantial engagement with otherness, and what could be termed as, "the connection of a multiplicity of molecular desires...that should act to catalyse change on a larger scale,” (Guattari, 1995, pp. 230-231). In our case it is through teachers capitalising on the narratives of otherness in education to build strong links between their curricula provision and the conceptual and affective growth of everyone in the places where they work.

\section{CONCLUSION}

In conclusion, I would like to take us back to the one of the sources of otherness in Deleuze, and that is the writings of Friedrich Nietzsche. In a lecture about the philosophy of Nietzsche, Fred Ulfers (1999) explains how he integrated otherness into being:

When I said self-same, self-contained beings; the notion of being is important here because it's not an aspect of the 'given-ness' of a self but the result of the violence of simplification and falsification of the singular, whose otherness can never be reduced to the 'is', the self-presence of being, since it is radically temporal, event-like, constituting continual transitoriness and fleetingness.

As such the Nietzchean conception of otherness built a picture of the self that may act as a springboard for Deleuze's singularities and nomadism. In education these are non-foundational moments; that may come along during class time or more likely as we consider our teaching strategies and results, and ruminate about the ways in which we may improve and enhance the student's experience. Otherness leads away from the social and cultural perspective of education; that may be vaunted as a means to giving students social justice and egalitarian rights (McLaren, 1989). This does not mean that concentrating on the narratives of otherness excludes the social/critical elements of education, but that it does 
enhance and perhaps capture many of aspects of mainstream provision that have previously 'slipped beneath the radar' in the western educational machine. As David Geoffrey Smith (1999) has put it in dramatic terms, "In the ocean of wisdom, the moment Self and Other have been identified they have disappeared, or been transformed or mutated into yet another unfolding of the drama in which all things, all people regardless of race, gender or class participate,” (p. 24). I am reluctant to put it in those terms, but certainly this statement resonates with Deleuze \& Guattari’s $(1984,1988)$ work on otherness.

The point here is that Deleuze (1983) gives us a means and focus to deal with otherness in education. In his early work, Nietzsche and Philosophy, he signalled this intent by exploring multiplicity, becoming and affirmation. These three factors represent a politics of difference, through which we may integrate otherness into education. It is an ethical stance, that takes the passion and desires present in educational contexts, and proposes a way of working that does not suppress, hide or sublimate these forces, but indicates points of contact through change and narrative forms to make education better.

\section{REFERENCES}

Ansell Pearson, K. (1999). Germinal Life: The difference and Repetition of Deleuze. London: Routledge.

Badiou, A. (1994). The Fold: Leibniz and the Baroque. In: C.V. Boundas \& D. Olkowski (Eds.), Gilles Deleuze \& the theatre of philosophy (pp. 43-73). London: Routledge.

Balsamo A. (1996). Technologies of the Gendered Body: Reading Cyborg Women. Durham, NC: Duke University Press.

Braidotti, R. (2005). Affirming the Affirmative: On Nomadic Affectivity. Rhizomes 11/12 fall 2005/spring 2006. Retrieved 19/07/06 from: http://www.rhizomes.net/issue11/braidotti.html

Colebrook, C. (2002). Understanding Deleuze. Crows Nest, NSW: Allen \& Unwin.

Davies, B. (2005). The (Im)possibility of Intellectual Work in Neoliberal Regimes. Discourses: studies in the cultural politics of education. Vol. 26, No. 1, March 2005, pp. 1-14.

Davis, M. (1990). city of quartz: excavating the future in Los Angeles. London: Vintage.

Deleuze, G. (1988). Bergsonism (H. Tomlinson \& B. Habberjam Trans.). New York: Zone Books. (Original work published 1966).

Deleuze, G. (1994a). Difference \& Repetition (P. Patton Trans.). New York: Columbia University Press. (Original work published 1968).

Deleuze, G. (1997). Desire \& Pleasure Trans. M. McMahon. Retrieved 21/10/2004 from: http://www.arts.monash.edu.au/visarts/globe/issue5/delfou.html (Original work written 1977).

Deleuze, G. (1994b). He stuttered. In: C. V. Boundas \& D. Olkowsky (Eds.), Gilles Deleuze and the theatre of Philosophy (pp. 23-33). London: Routledge.

Deleuze, G. (1983). Nietzsche and Philosophy (H. Tomlinson Trans.). London: the Athlone Press. (Original work published 1962).

Deleuze, G. (1990). The Logic of Sense (M. Lester \& C. Stivale Trans.). New York: Columbia University Press. (Original work published 1969).

Deleuze, G., \& Guattari, F. (1984). Anti-Oedipus: Capitalism \& Schizophrenia (R. Hurley, M. Seem \& H. R. Lane Trans.). London: The Athlone Press. (Original work published 1972).

Deleuze, G., \& Guattari, F. (1988). A Thousand Plateaus: Capitalism \& Schizophrenia Part 2 (B. Massumi Trans.). London: The Athlone Press. (Original work published 1980). 


\section{DELEUZE AND THE NARRATIVE FORMS OF EDUCATIONAL OTHERNESS}

Deleuze, G., \& Guattari, F. (1986). Kafka: Toward a Minor Literature (D. Polan Trans.). Minneapolis: University of Minnesota Press. (Original work published 1975).

Einstein, A. (1920). Relativity: the special and the general theory: a popular exposition (R. W. Lawson Trans.). London: Methuen \& Co Ltd.

Ellul, J. (1964). The Technological Society. London: Jonathan Cape. (Original work published 1954).

Gee, J. P. (2004). What video games have to teach us about learning and literacy. Palgrave: Macmillan Press.

Golding, S. (1997). Eight technologies of otherness. London: Routledge.

Guattari, F. (1995). Chaosophy: An Ethico-Aesthetic Paradigm (P. Bains \& J. Pefanis Trans.). Bloomington: Indiana University Press.

Habermas, J. (1999). The Structural Transformation of the Public Sphere: An Inquiry into a Category of Bourgeois Society (T. Burger Trans.). Cambridge, Mass.: MIT Press. (Original work published 1962).

Haraway, D. (1991). A Cyborg Manifesto: Science, Technology, and Socialist-Feminism in the Late Twentieth Century. In: Simians, Cyborgs and Women: The Reinvention of Nature (pp. 149-181). New York: Routledge.

Harding, S. (1986). The Science Question in Feminism. Milton Keynes: Open University Press.

Hardt, M. (1993). Gilles Deleuze: An apprenticeship on philosophy. London: UCL Press.

Hollinger, V., \& Gordon, J. (2002). Edging into the Future: Science Fiction and Contemporary Cultural Transformation. Pennsylvania: University of Pennsylvania Press.

Jünger, F. (1949a). Die Perfektion der Technik. Frankfurt: Klostermann.

Jünger, F. (1949b). Maschine und Eigentum. Frankfurt: Klostermann.

Kadrey, R. (1995). Metrophage. Electronic document retrieved 6/12/02 from: http://www.speed.demon.co.uk/kadrey/metro3.txt

Landa, M. (1991). War in the Age of Intelligent Machines. New York: Zone Books.

Lash, S., \& Urry, J. (1994). Economies of Signs \& Space. London: Sage Publications.

Leach, M., \& Boler, M. (1998). Gilles Deleuze: Practicing Education through flight and gossip. In: M. Peters (Ed.), Naming the Multiple: Poststructuralism and Education (pp. 149-172). Westport, Conn.: Bergin \& Garvey.

Lyotard, J. (1984). The Post-modern Condition: A Report on Knowledge (G. Bennington \& B. Massumi Trans.). Minneapolis, MN: University of Minnesota Press. (Original work published 1979).

McLaren, P., \& Leonardo, Z. (1998). Jean Baudrillard: From Marxism to Terrorist Pedagogy. In: M. Peters (Ed.), Naming the Multiple: Poststructuralism and Education (pp. 215-244). Westport, Conn.: Bergin \& Garvey.

McLaren, P. (1989). Life in Schools: An Introduction to Critical Pedagogy in the Foundations of Education. New York: Longman.

Murphie, A. (2005). Differential Life, Perception and the nervous elements: Whitehead, Bergson and Virno on the technics of living. Culture Machine 2005 (EJ). Retrieved 25/08/2005 from: http://culturemachine.tees.ac.uk/Articles/murphie.htm

New London Group. (1996). A pedagogy of multiliteracies: Designing social futures. Harvard Educational Review, 66:1, 60-92.

Parisi, L. (2004). Abstract Sex: Philosophy, Bio-technology and the mutations of desire. London: Continuum.

Peters, M. (1996). Poststructuralism, Politics and Education. Westport, Conn.: Bergin \& Garvey.

Seaton, A. (2002). Reforming the Hidden Curriculum: The Key Abilities Model and Four Curricular Forms. Curriculum Perspectives 22 (1).

Selfridge, O. G. (1958). Pandemonium: A paradigm for learning. In Mechanisation of Thought Processes: Proceedings of a Symposium Held at the National Physical Laboratory. London: HMSO.

Semetsky, I. (2004). Becoming-Language/Becoming-Other: Whence Ethics? Educational Philosophy and Theory, Vol. 36, No. 3, 2004, 313-325.

Shields, B. (Ed.) (1996). Virtual Spaces, Real Histories, Living Bodies. London: Sage Publications.

Smith, D.G. (1999). Pedagon: Interdisciplinary Essays in the Human Sciences, Pedagogy, and Culture. New York: Peter Lang. 
DAVID R. COLE

Ulfers, F. (1999). Nietzsche's Ethics Beyond Good and Evil: A lecture by Fred Ulfers. Retrieved 02/08/06 from: http://www.egs.edu/faculty/ulfers/ulfersnietzsche-beyond-good-and-evil-1999.html

Wittgenstein, L. (1998). Philosophical Investigations (G.E.M. Anscombe Trans.). Oxford: Blackwell Publishers. (Original work published 1953).

Whitehead, A.N. (1978). Process \& reality: An essay in cosmology. New York: The Free Press. (Original work published 1929).

David R. Cole

Faculty of Education

University of Tasmania

Australia. 